the tail vein of the mice and the blood sugar estimated. Blood glucose determination was made by the Hagedorn-Jenson method. In another group of ten $\mathrm{KK}$ strain of mice, alloxan $(40 \mathrm{mg} / \mathrm{kg})$ was administered intraperitoneally and the blood sugar estimated a week later.

The results showed that while the fasting blood sugar varied from $30.5 \mathrm{mg}$ to $50.94 \mathrm{mg}$ there was a hypoglycemic response to $20 \mathrm{mg} / \mathrm{kg}$ of oral tolbutamide in every animal. The percentage fall in the blood sugar level was $30.4,61.4,36.4,38.4,40.3,18.9,13.5,51.8,36.3$ and 12.7 in ten mice. In the ten mice to which alloxan $(40 \mathrm{mg} / \mathrm{kg}$ i.p.) had been administered a week prior to the test there was a rise in the blood sugar level in every animal. The percentage rise in the blood sugar was 312.8, 17.1, 127.4, 355.3, 218.9, 235.4, 194.2, 218.9, 52.1 and 117.7 in ten $\mathrm{KK}$ strain of mice after alloxan.

These results obtained with the KK strain of mice indicate that tolbutamide does cause a fall in the blood sugar level in these micc. These mice could, therefore, be satisfactorily used for the screening of substances which have a mechanism of action similar to tolbutamide. The rise in the blood sugar level after administration of alloxan indicates that these animals respond in a similar way as normal mice to alloxan in spite of the fact that the pancreas contains more insulin than present normally in mice pancreas (1).

\title{
REFERENCE
}

1) Nakamura, M.: Proc. Japan Acad. 38, 348 (1962)

\section{PERIPHERAL COMPONENT IN RESERPINE INDUCED MIOSIS}

\author{
M.L. GUPTA, B.P. JAJU AND K.P. BHARGAVA \\ Department of Pharmacology $\mathcal{G}$ Therapeutics, K.G's Medical College, Lucknow University, Lucknow-3, India
}

Received for publication December 18, 1967

Reserpine, on systemic administration (1) as well as after intracerebroventricular injection (2), exerts parasympathomimetic effects such as miosis, salivation, and diarrhoea. These effects have been attributed to increased central parasympathetic activity since reserpine increases the acetylcholine contents of the hypothalamus (3). A direct parasympathomimetic action of reserpine has been excluded by Beckman (4). However these observations do not exclude the possibility of a peripheral component of action in the reserpine induced miosis. Therefore, it was planned to study the effect of topical application of reserpine on the pupillary size in rabbits. Four adult albino rabbits of either sex weighing from 1.0 to $1.4 \mathrm{~kg}$ were employed in the present study. The drug was applied topically as $0.1 \%$ ointment in one eye while in the other eye (control eye) only vaseline was applied. The ointment was applied daily for seven days and the pupillary size was measured each day before the application of the drug. Pupillary size was measured according to the method of Chen and Way (5) suitably modified by providing gradually increasing sized apertures instead of the black dots. The pupil was continously observed for one minute through the appropriate aperture of the pupillometer kept at a constant distance from the rabbit eye and the diameter noted.

TABLE 1. Effect of topical application of reserpine on pupillary diameter.

\begin{tabular}{ccc}
\hline $\begin{array}{c}\text { Number of } \\
\text { rabbits }\end{array}$ & \multicolumn{2}{c}{ Average diameter of rabbit pupil \pm S.E. in $\mathrm{mm}$} \\
\cline { 2 - 3 } & Control eye & Treated eye \\
\hline 4 & $7.38 \pm 0.21$ & $5.90 \pm 0.12$ \\
\hline
\end{tabular}

S.E. : Standard error 
The results of this study are summarized in Table 1 . It is evident that in the reserpine treated eye, the average pupillary diameter was $5.90 \pm 0.12 \mathrm{~mm}$ as compared to the control eye $(7.38 \pm 0.21 \mathrm{~mm})$. Absence of any change in the pupillary size of the control eye in all these rabbits rules out the possibility of central or sys semic action. Conjunctival or corneal irritation can be excluded since there was no lacrymation or redness of the conjunctiva upon local application of reserpine. The mechanism of the local miotic action of reserpine is open to speculation. Reserpine has been shown to decrease the catecholamine contents of the iris (6). It could be that depletion of catecholamines by reserpine may lead to sympathetic inactivity and this may be responsible for the parasympathetic preponderance. The relative importance of the peripheral action of reserpine in comparison to the centrally induced miosis by systemic administration of reserpine cannot be stated.

Acknowledgement: This work was supported by a grant from the Council of Scientific and Industrial Research, New Delhi.

\title{
REFERENCES
}

1) Bein, H.J.: Experientia 9. 107 (1953); 2) Thomas, J.H.: Psychotropic Drugs, Edited by S. Garattini and V. Ghetti, p. 284, Elsevier, Amsterdam (1957); 3) Malhotra, C.L. and Prasad, K.: Br. J. Pharmac. Chemother. 21, 355 (1963); 4) Beckman, H.: The Nature, Action and Use of Drugs, 2nd ed., p. 291, W.B. Saunders, Philadelphia and London (1961); 5) Chen, I.Y. And Way, E.L.: Br. J. Pharmac. Chemother. 24, 789 (1965); 6) Burn, J.H. And Rand, M.J.: J. Physiol. 147, 135 (1959)

\section{ACGUMULATION OF DIGITOXIN BY THE HEART AND "THE GUMULATIVE EFFECT OF DIGITALIS"}

\author{
TAKASHI IZUMI, SUMIKO FUJINO, SATOSHI \\ YOROZUYA AND MAMORU TANAKA \\ Department of Pharmacology, Sapporo Medical College, Sapporo
}

Received for publication January 10, 1968

There exists a considerable literature (1-4) on "the cumulative effect of digitalis", but the mechanism involved in the appearance of "the cumulative effect" is still a matter of speculation. The present work was designed to know whether "the cumulative effect of digitalis" occurs as a result of the real accumulation of digitalis or is due to digitalis-induced change in the heart tissue. Experiment was carried out with cats and guinea pigs. At various times after a single intravenous injection of $0.132 \mathrm{mg} / \mathrm{kg}$ digitoxin in cats or of 0.750 $\mathrm{mg} / \mathrm{kg}$ digitoxin in guinea pigs, the following observations were made; 1) determination of lethal dose of digitoxin by Hatcher's method, 2) measurement of glycosides (digitoxin and its metabolites) content in the heart by Repke's method (5), 3) patho-histological examination of the heart tissue.

The lethal dose of digitoxin in cats decreased markedly 24 hours after the administration of the drug, reaching the half of the control value 48 hours later. The significant decrease in the lethal dose was still recognized about 10 days after the drug administration. Thus, it can be said that, in cats, the cumulative effect of digitoxin is quite remarkable. In guinea pigs, however, "the cumulative effect of digitoxin" could 